\title{
BAHAN AJAR PROBLEM SOLVING BERBASIS OPEN-ENDED PADA PEMBELAJARAN MATEMATIKA UNTUK MENGEMBANGKAN KEMAMPUAN PENALARAN MAHASISWA PGSD
}

\author{
Jasmaniah, Fachrurazi, dan Ety Mukhlesi Yeni \\ PGSD, Universitas Almuslim, Email: jasmaniahPGSD@yahoo.com \\ PGSD, Universitas Almuslim, Email: fachrurazi.aroel@yahoo.co.id \\ PGSD, Universitas Almuslim, Email: emyitsme@gmail.com
}

\begin{abstract}
ABSTRAK
Problem solving menjadi fokus penting dalam pembelajaran matematika. Dalam banyak kasus, para siswa seringkali merasa bahwa suatu pendekatan aljabar merupakan satu-satunya pendekatan yang akan bekerja. Hal ini sangatlah beralasan kiranya karena dalam proses pembelajaran matematika selama ini siswa hanya diajarkan dengan pendekatan tersebut untuk menyelesaikan suatu soal cerita dan sejenisnya. Bahkan ada sejumlah guru yang mengajar matematika di SD melompati materi yang akan diajarkan ketika dalam proses pembelajaran berjumpa dengan soal-soal problem solving. Banyak buku teks matematika sekolah dasar juga cenderung menekankan peran soal cerita tradisional untuk mengembangkan kemampuan-kemampuan problem solving. Dari masalah tersebut kiranya dapat dipahami bahwa merancang suatu bahan ajar yang didalamnya memuat soal-soal untuk membangun kemampuan problem solving berbasis open ended dan mengembangkan kemampuan penalaran mahasiswa PGSD Universitas Almuslim merupakan sesuatu hal yang sangat urgen. Hal ini dimaksudkan agar mahasiswa PGSD sebagai calon guru SD mempunyai bekal yang memadai mengenai pemahaman problem solving ketika akan mengajar di SD. Penelitian ini ingin menghasilkan bahan ajar problem solving dalam pembelajaran matematika untuk meningkatkan kemampuan penalaran mahasiswa PGSD. Penelitian ini menggunakan metode penelitian dan pengembangan (Research and Development). Adapun hasil yang diperoleh sejauh ini pada tahun pertama adalah telah dilaksanakan 5 (lima) langkah dari 6 (enam) langkah yang direncanakan yakni; 1) mengumpulkan informasi mengenai proses pembelajaran matematika dalam aspek pemecahan masalah yang sudah dilakukan guru di SD dan di perkuliahan, 2) desain bahan ajar problem solving berbasis open ended, 3) validasi desain bertujuan untuk menilai rancangan bahan ajar dengan menghadirkan 2 ahli (ahli materi dan ahli media) untuk mengetahui kelemahan dari bahan ajar yang di rancang, 4) perbaikan desain hasil validasi, 5) uji coba bahan ajar problem solving berbasis open ended, baik uji coba secara terbatas maupun secara luas, dan 6) revisi bahan ajar berdasarkan uji coba secara terbatas dan luas (masih sedang dilaksanakan).
\end{abstract}

Kata kunci: bahan ajar, problem solving, open-ended, dan penalaran.

\section{ABSTRACT}

Problem solving becomes an important focus in the learning of mathematics. In many cases, students often feel that an algebraic approach is the only approach that will work. This is groundless presumably because the mathematics learning process for these students were only taught the approach to solve story problems and the like. In fact, there are a number of teachers who teach mathematics in elementary jump over the material that will be taught when in the learning process met with problems solving. Many elementary school mathematics textbooks also tend to emphasize the role of the traditional story problems to develop problem solving skills. Of these problems would be understood that designing a teaching material which includes the questions to build capabilities based on open-ended problem solving and reasoning skills students develop PGSD University Almuslim is something very urgent. It is intended that students PGSD as prospective elementary school teachers have adequate provisions regarding the understanding of problem solving when it will be taught in elementary school. This study wants to produce teaching materials in mathematics problem solving to improve the reasoning ability of students PGSD. This study uses research and development (Research and Development). The results obtained so far in the first year was to have been held 5 (five) steps out of 6 (six) planned measures namely; 1) collecting information on the process of learning mathematics in the aspect of solving the problem that has been done teacher in elementary school and in college, 2) design teaching materials problem solving based on open-ended, 3) design validation in order to assess the design of teaching materials by presenting two experts (expert material and media experts) to identify the weaknesses of the teaching materials are designed, 4) improvement of design validation results, 5) test teaching material problem solving based on open-ended both trials in limited or wide, and 6) the revision of teaching materials based test try a limited basis and spacious (still being implemented).

Keywords: teaching materials, problem solving, open-ended, andreasoning. 


\section{PENDAHULUAN}

Dari tahun ke tahun problem solving muncul sebagai salah satu perhatian utama di tingkatan matematika sekolah. The National Council of Supervisors of Mathematics (NSCM) menyatakan bahwa "belajar menyelesaikan masalah adalah alasan utama untuk mempelajari matematika" (NSCM, Position Paper on Basic Mathematics, 1977 dalam Wahyudin, 2010). The National Council of Teachers of Mathematics (NCTM) menyatakan secara tegas bahwa "Problem solving bukanlah sekadar tujuan dari belajar matematika, tetapi juga merupakan alat utama untuk melakukannya" (NCTM, 2000).

Dari pendapat NCTM kita dapat pahami bahwa problem solving sebagai focus sentral dari kurikulum matematika. Tidak saja kemampuan untuk memecahkan masalah menjadi alasan untuk mempelajari matematika, tetapi problem solving pun memberikan suatu konteks di mana konsep-konsep dan kecakapan dapat dipelajari (Wahyudin, 2010:356). Selain itu, problem solving merupakan wahana untuk membangun kecakapan-kecakapan berpikir tingkat tinggi.

Dalam banyak kasus, para siswa tampaknya merasa bahwa suatu masalah hanya dapat diselesaikan dalam satu cara saja, yang khusus bagi jenis masalah yang sedang diajarkan (misal soal tentang perpindahan, usia, soal campuran, dan sebagainya). Para siswa seringkali merasa bahwa suatu pendekatan aljabar merupakan satu-satunya pendekatan yang akan bekerja. Hal ini sangatlah beralasan kiranya karena dalam proses pembelajaran matematika selama ini siswa hanya diajarkan dengan pendekatan tersebut untuk menyelesaikan suatu soal cerita dan sejenisnya. Bahkan ada sejumlah guru yang mengajar matematika di SD melompati materi yang akan diajarkan ketika dalam proses pembelajaran berjumpa dengan soal-soal problem solving (Jasmaniah, 2012). Hal ini menunjukkan bahwa pembelajaran problem solving hampir jarang bahkan tidak pernah disentuh guru dalam proses pembelajaran di SD.
Karakter mahasiswa PGSD berdasarkan pengamatan Supriadi (2009) adalah pertama, mahasiswa PGSD cenderung menyenangi soal-soal yang berbentuk rutin sehingga saat diberikan soal-soal yang bersifat tidak rutin mereka cenderung kesulitan. Kedua, pada umumnya kemampuan mahasiswa PGSD dalam penyelesaian permasalahan matematika dapat dikategorikan sedang dan rendah, jarang sekali mahasiswa yang berkemampuan tinggi. Ketiga, suasana kegiatan belajar mengajar mahasiswa PGSD cenderung tidak terlalu aktif.

Faktor soal yang disajikan dalam buku teks matematika saat ini juga jadi faktor lain selain kemampuan guru. Sebagian besar soal dalam buku teks hanya bersifat terkait latihan (practice related) pada topik berhitung sebuah bab. Jika para siswa hanya melakukan apa yang terakhir diajarkan kepada mereka, maka mereka akan mampu menjawab dangan benar $60-80 \%$ dari soal buku teks, bahkan meski tanpa membaca soalnya (Wahyudin, 2010:356).

Banyak buku teks matematika sekolah dasar juga cenderung menekankan peran soal cerita tradisional untuk mengembangkan kemampuan-kemampuan problem solving. Beberapa kelemahan umum menurut Wahyudin (2010:479) yang terdapat dalam buku teks matematika SD antara lain:

a. Soal-soal cerita yang hanya dijadikan suatu bagian diakhir bab, tidak senantiasa hadir disepanjang pembelajaran;

b. Soal-soal cerita yang tampak hanya ditujukan untuk menguasai konsepkonsep yang sedang dipelajari dalam unit tertentu, tidak mengintegrasikan topik-topik dari berbagai unit dan subyek;

c. Soal-soal cerita yang cenderung berfokus pada satu interpretasi spesifik mengenai suatu operasi, seperti hanya pengurangan mengambil atau hanya pembagian dan secara demikian menyempitkan perspektif siswa tentang bagaimana operasi-operasi itu 
dapat diinterpretasikan dalam berbagai cara;

d. Soal cerita yang ditulis sedemikian hingga siswa terkondisikan mencari kata-kata kunci untuk menginterpretasikan apa yang hendak dilakukan daripada berfokus mencari petunjuk-petunjuk konteks dalam tindakan yang berlangsung; dan

e. Soal soal cerita yang bersifat terlalu menyederhanakan aplikasi-aplikasi yang hendak didemontrasikannya.

Rendahnya kemampuan pemecahan masalah dapat diketahui dari laporan The Trends in International Mathematics and Science Study (TIMSS) 2011 bahwa prestasi matematika siswa indonesia berada pada urutan ke-38 dari 42 negara dengan skor ratarata 386 (Mullis et al dalam Murni 2013:1). Adapun kerangka penilaian TIMSS meliputi dimensi kontent dan dimensi kognitif. Dimensi kognitif terdiri dari empat domain, yaitu: mengetahui fakta dan prosedur, menggunakan konsep, memecahkan masalah rutin dan menggunakan penalaran. Lebih lanjut hasil studi The Programme for International Student Assessment (PISA) 2009 menyatakan bahwa kemampuan matematis siswa Indonesia berada pada peringkat ke-61 dari 65 negara dengan skor rata-rata 371 (Tjalla dalam Murni, 2013:2). Kemampuan siswa terlihat rendah dalam hal menemukan algoritma, menginterpretasikan data, dan menggunakan langkah-langkah dalam menyelesaikan masalah.

Hasil studi TIMMS dan PISA tersebut memberikan gambaran bahwa siswa Indonesia memiliki kemampuan rendah dalam menjawab soal-soal berstandar internasional terutama pada kemampuan pemecahan masalah matematis. Hal ini karena dalam pembelajaran matematika siswa belum terbiasa menyelesaikan soal non rutin yang menantang siswa untuk berpikir. Selain itu pelaksanaan pembelajaran matematika selama ini juga cenderung hanya mengacu pada buku teks dengan langkah menyajikan materi, memberikan contoh soal, meminta siswa mengerjakan latihan yang terdapat dibuku teks, dan kemudian membahas bersama siswa. Hal yang lebih miris lagi seperti yang telah dipaparkan sebelumnya bahwa kemampuan guru yang masih sangat minim terhadap kemampuan pemecahan masalah (problem solving).

Dari paparan di atas kiranya dapat dipahami bahwa merancang suatu bahan ajar yang didalamnya memuat soal-soal open-ended problems untuk membangun kemampuan problem solving siswa dan meningkatkan kemampuan penalaran matematika mahasiswa PGSD sebagai calon guru SD merupakan sesuatu hal yang sangat urgen. Hal ini dimaksudkan agar para calon guru mempunyai bekal yang memadai mengenai pemahaman problem solving ketika akan mengajar di SD. Penekanan bahan ajar problem solving ini pada berbasis open ended, karena pendekatan ini menjanjikan suatu kesempatan kepada mahasiswa untuk menginvestigasi berbagai strategi dengan cara yang diyakininya sesuai dengan kemampuan mengelaborasi permasalahan. Senada dengan itu Tim MKPBM Jurusan Pendidikan Matematika UPI Bandung (2011) menyatakan bahwa mahasiswa dihadapkan pada problem open ended bertujuan untuk tidak saja mendapatkan jawaban, tetapi lebih menekankan pada cara bagaimana sampai pada suatu jawaban.

Berdasarkan uraian pada latar belakang di atas, maka pertanyaan penelitian ini adalah:

1. Desain bahan ajar problem solvingberbasis open-ended seperti apakah yang sesuai dilaksanakan oleh mahasiswa PGSD Universitas Almuslim?

2. Bagaimana tingkat keterapan bahan ajar problem solving berbasis open-ended yang dihasilkan dilihat dari aspek kemampuan penalaran mahasiswa PGSD Universitas Almuslim?

3. Bagaimana dampak penerapan bahan ajar problem solving berbasis openended problems yang dihasilkan terhadap aspek peningkatan kemampuan penalaran mahasiswa PGSD universitas Almuslim? 
Kajian literatur yang digunakan dalam penelitian ini adalah:

\section{Masalah Open Ended}

Pendekatan Open-ended merupakan salah satu upaya inovasi pendidikan matematika yang pertama kali dilakukan oleh para ahli pendidikan matematika Jepang. Pendekatan ini lahir sekitar duapuluh tahun yang lalu dari hasil penelitian yang dilakukan Shigeru Shimada, Toshio Sawada, Yoshiko Yashimoto, dan Kenichi Shibuya (Nohda, 2000). Pendekatan open-ended menjanjikan suatu kesempatan kepada peserta didik untuk menginvestigasi berbagai strategi dan cara dalam menyelesaikan masalah. Munculnya pendekatan ini sebagai reaksi atas pendidikan matematika sekolah saat itu yang aktifitas kelasnya bersifat frontal teaching; guru mentransfer sejumlah pengetahuan kepada peserta didik dengan berceramah di depan kelas, kemudian memberikan contoh untuk penyelesaian beberapa soal dan diikuti dengan latihan. Kondisi ini jelas membuat siswa belajar hanya sekadar saja, tetapi tidak sampai pada pemahaman yang lebih mendalam.

Gambaran yang telah diungkapkan di atas, seperti diketahui bahwa masalah rutin yang biasa diberikan pada siswa sebagai latihan atau tugas selalu berorientasi pada tujuan akhir, yakni mendapatkan satu jawaban yang benar. Akibatnya proses atau prosedur yang telah dilakukan oleh siswa dalam menyelesaikan soal tersebut kurang atau bahkan tidak mendapat perhatian guru. Padahal perlu disadari bahwa proses penyelesaian masalah merupakan tujuan utama dalam pembelajaran pemecahan masalah matematika. Gambaran tersebut sebagaimana dikemukakan Anthony (1996) yang mengemukakan bahwa pemberian tugas matematika rutin yang diberikan pada latihan atau tugas-tugas matematika selalu terfokus pada prosedur dan keakuratan, jarang sekali tugas matematika terintegrasi dengan konsep lain dan juga jarang memuat soal yang memerlukan kemampuan berfikir tingkat tinggi.
Berdasarkan gambaran tersebut, kiranya dapat dipahami bahwa memberikan masalah yang bersifat terbuka, akan mendorong siswa untuk melakukan proses matematika. Pada akhirnya kondisi ini akan mendorong siswa untuk mengembangkan kemampuan berfikir tingkat tinggi.

Masalah open-ended disebut juga masalah terbuka karena masalah ini diformulasikan memiliki multijawaban yang benar. Menurut Takahashi (2006), soal terbuka (open-ended problem) adalah soal yang mempunyai banyak solusi atau strategi penyelesaian. Sedangkan menurut Syaban (2008), dipandang dari strategi bagaimana materi pelajaran disampaikan, pada prinsipnya pembelajaran dengan memanfaatkan soal terbuka dapat dipandang sebagai pembelajaran berbasis masalah, yaitu suatu pembelajaran yang dalam prosesnya dimulai dengan memberi suatu masalah kepada siswa. Hal ini sesuai dengan pendapat Shimada (1997) bahwa pembelajaran openended adalah pembelajaran yang menyajikan suatu permasalahan yang memiliki metode atau penyelesaian yang benar lebih dari satu. Pembelajaran open-ended dapat memberi kesempatan kepada siswa untuk memperoleh pengetahuan/pengalaman menemukan,mengenali, dan memecahkan masalah dengan beragam teknik.

Aspek keterbukaan dalam soal open ended dapat diklasifikasikan ke dalam tiga tipe,yaitu: (1) terbuka proses penyelesaiannya, yakni soal itu memiliki beragam cara penyelesaian, (2) terbuka hasil akhirnya, yakni soal itu memiliki banyak jawab yang benar, dan (3) terbuka pengembangan lanjutannya, yakni ketika mahasiswa telah menyelesaikan sesuatu, selanjutnya mereka dapat mengembangkan soal baru dengan mengubah syarat atau kondisi pada soal yang telah diselesaikan. Masalah open-ended dibagi menjadi 3, yaitu:

\section{(a) masalah open-ended pendek (short open-ended problems)}

Guru dapat menggunakan short openended problems dalam pemecahan masalah 
matematika yang lebih memfokuskan pada bagaimana mengajarkan isi atau materi matematika (teaching via problem solving) untuk mengembangkan kemampuan materi matematika dan kemampuan komunikasi mahasiswa.Karakter dari masalah openended adalah memungkinkan banyak jawaban dan penyelesaian dengan banyak cara. Masalah dalam short open-ended problems bukanlah masalah yang kompleks dan rumit tetapi masalah yang memiliki struktur yang sederhana.

\section{(b) Aplikasi masalah kehidupan sehari- hari (applied real-life problems)}

Pemecahan masalah yang dihadapi setiap individu dalam situasi setiap saat dimulai dengan situasi masalah dalam kehidupan sehari-hari (applied real-life problems) kemudian mengaitkan yang ada hubungannya dalam memahami masalah matematika.

\section{(c) Investigasi matematika (mathematical investigations)}

Umumnya aktivitas mahasiswa dalam openended adalah menyelidiki dan memperbaiki kemampuan matematika murni untuk kepentingan dirinya sendiri. Kebanyakan memandang investigasi sebagai proses pemecahan masalah yang besar dalam open-ended, yang dapat dikembangkan dengan cara berbeda untuk mahasiswa yang berbeda. Mahasiswa diberi kesempatan dalam mengembangkan perumpamaan hasil berdasarkan penyelidikan, pentabulasian data untuk melihat contoh, membuat perkiraan dan melakukan uji coba, serta membenarkan perumusan yang mereka temukan.

\section{Penalaran Matematika}

Penalaran dan pembuktian matematika menawarkan suatu cara untuk mengembangkan wawasan mahasiswa tentang fenomena. Orang yang nalar dan berpikirnya analitik cenderung mencatat pola, struktur, dan keteraturan dalam situasi nyata (real-word)dan benda-benda simbolik (Turmudi, 2008). Permasalahan dalam dunia matematika adalah bagaimana menghasilkan suatu konsep dari konsep yang sudah diketahui, hal ini bisa dipecahkan, dibutuhkan kemampuan penalaran yang memadai sehingga langkah demi langkah penyelesaiannya akan terarah dan sistematis.

Menurut Schonfeld dalam Sumarmo (2004), matematika merupakan proses yang aktif, dinamik, generatif dan eksploratif. Berarti bahwa proses matematika dalam penarikan kesimpulan merupakan kegiatan yang membutuhkan pemikiran dan penalaran tingkat tinggi. Beberapa indikator penalaran matematik (Sumarmo, 2004) dalam pembelajaran matematika antara lain, mahasiswa dapat: 1) Menarik kesimpulan logik, 2) Memberikan penjelasan dengan model, fakta, sifat-sifat dan hubungan, 3) Memperkirakan jawaban dan proses solusi, 4) Mengunakan pola dan hubungan untuk menganalisis situasi matematik, 5) Menyusun dan menguji konjektur, 6) Merumuskan lawan contoh (counter example), 7) Mengikuti aturan inferensi; memeriksa validitas argumen, 8) Menyusun argumen yang valid, 9) Menyusun pembuktian langsung, tak langsung dan menggunakan induksi matematik.

Depdiknas (2002) menyatakan bahwa materi matematika dan penalaran matematika adalah dua hal yang tidak dapat dipisahkan, yaitu materi matematika dipahami melalui penalaran dan penalaran dipahami dan dilatihkan melalui belajar materi matematika. Penalaran ini tidak hanya dibutuhkan oleh mahasiswa dalam mempelajari matematika ataupun ilmu-ilmu lainnya, lebih dari itu, penalaran menjadi penting untuk memecahkan masalah kehidupan nyata yang dihadapinya (Shadiq, 2004).

\section{Rancangan Bahan Ajar Open Ended Pada Pembelajaran Matematika}

Bahan ajar adalah seperangkat materi yang disusun secara sistematis baik tertulis maupun tidak sehingga tercipta lingkungan/ suasana yang memungkinkan mahasiswa untuk belajar. Bahan ajar dalam penelitian ini adalah berupa bahan ajar cetak yang berbentuk Lembar Kerja Mahasiswa (LKM). Adapun cakupan bahan ajar yang akan 
dihasilkan meliputi: (1) Judul Bahan Ajar;

(2) Indikator Pembelajaran; (3) Tujuan pembelajaran; (4) Deskripsi Materi; (5)

Kegiatan Pembelajaran; dan (6) Lembar Kegiatan Mahasiswa.

\section{METODE PENELITIAN}

Penelitian ini menggunakan metode Research and Development $R$ \& $D$ (Sugiyono, 2010:431). Metode ini dipilih karena pada tahap pertama akan dilakukan kajian (research) terhadap proses pembelajaran matematika menyangkut aspek pemecahan masalah yang diajarkan oleh guru di SD dan kemudian berdasarkan hasil kajian itu merumuskan bahan ajar problem solving berbasis open ended dalam pembelajaran matematika beserta uji coba dari bahan ajar tersebut baik uji coba secara terbatas maupun uji coba lebih luas. Berdasarkan dari metode yang digunakan, penelitian ini terdiri dari 3 tahapan, yaitu: tahap 1: tahap studi pendahuluan; tahap 2: tahap studi pengembangan; dan tahap 3: tahap evaluasi.

\section{HASIL DAN PEMBAHASAN}

Berdasarkan metode penelitian yang diajukan, penelitian ini dirancang untuk 2 tahun dalam tiga tahapan, yaitu tahap studi pendahuluan, tahap studi pengembangan, dan tahap evaluasi. Tahap studi pendahuluan dan studi pengembangan merupakan tahapan pada tahun pertama penelitian, sedangkan tahap evaluasi merupakan tahapan pada tahun kedua penelitian.

\section{Tahap Studi Pendahuluan}

Pada tahap ini peneliti mengumpulkan data dengan studi literatur dan studi lapangan.Studi literatur dalam penelitian ini meninjau hasil-hasil penelitian yang terkait dengan tema dari penelitian yang terdapat dan telah dilaksanakan di lokasi penelitian. Hasil menunjukkan belum ada yang melakukan penelitian mengenai desain bahan ajar problem solving berbasis openended pada pembelajaran matematika untuk mengembangkan kemampuan penalaran
mahasiswa.Sehingga hal ini membuat peneliti tertarik agar calon guru sekolah dasar mendapatkan pengalaman dan ilmu dalam menyelesaikan soal-soal problem solving berbasis open ended.

Berdasarkan studi lapangan didapatkan data bahwa dosen dalam perkuliahan yang terkait dengan bidang matematika kerap memberikan soal-soal problem solving, namun mahasiswa masih lemah dalam memahami dan menyelesaikan soal-soal problem solving tersebut. Mahasiswa masih kurang dalam memahami makna soal yang diberikan sehingga sulit mencari solusi terhadap masalah. Dosen harus menjelaskan terlebih dahulu maksud yang ditanyakan atau pernyataan yang diberikan dalam soal yang disajikan. Berdasarkan tanya jawab bersama mahasiswa, hal ini juga disebabkan karena selama di bangku sekolah menengah jarang mendapatkan soal-soal/masalah tipe problem solving, lebih kepada soal-soal yang prosedural atau yang biasanya ada dalam buku paket sekolah. Lebih lanjut, mahasiswa masih terfokus bahwa setiap soal yang diberikan hanya memiliki satu jawaban/solusi, tidak yakin bahwa terdapat soal-soal yang memiliki lebih dari satu jawaban. Pengakuan mahasiswa berikutnya bahwa ketika mereka akan menyelesaikan sebuah soal/masalah matematika, mereka cenderung berpikir bahwa pendekatan aljabar merupakan solusi untuk menyelesaikan soal tersebut.

Sebagai contoh, mahasiswa tampak bingung ketika diminta menunjukkan luas lingkaran dengan pendekatan luas persegi panjang, yang mereka tahu bahwa luas lingkaran adalah $\mathrm{L}=\pi r^{2}$. Sehingga, tidak yakin ketika disampaikan bahwa luas lingkaran dapat ditemukan dengan pendekatan bangun datar seperti persegi panjang, jajargenjang, trapezium, segitiga sama kaki, dan segitiga sama sisi. Kasus yang lain adalah mahasiswa sudah mampu untuk melakukan operasi hitung bilangan cacah, semisal $234+456$, akan tetapi mereka akan kebingungan dan ketika ditanyakan dari bilangan $0,1,2,3$, dan 4 , bentuklah 2 operasi hitung penjumlahan 
yang hasilnya kurang dari 400. Lebih lanjut mahasiswa juga masih sangat rendah pemahamannya mengenai bilangan pecahan dan decimal, terutama mengenai makna dasar bilangan pecahan dan perbandingan bilangan pecahan itu sendiri. Sebagai contoh mereka dominan menjawab bahwa $1 / 2>2 / 3$. Hal ini menunjukkan bahwa pembelajaran yang telah dilaksanakan selama ini belum mengarahkan mahasiswa untuk dapat memahami materi dengan tuntas.

Di sisi lain pada studi lapangan ini juga dilakukan tahap pendefinisian(define). Tujuan tahap pendefinisian ini adalah menetapkan dan mendefinisikan kebutuhan-kebutuhan pembelajaran dengan menganalisis tujuan dan batasan materi. Dari tahapan ini nantinya draft bahan ajar yang akan dirancang dan proses pembelajaran yang akan dilaksanakan. Tahap ini disusun oleh lima fase yaitu:

\section{a. Analisis awal-akhir (front-end analysis)}

Kegiatan analisis awal-akhir dilakukan untuk menetapkan masalah dasar yang diperlukan dalam pengembangan bahan ajar. Pada tahap ini dilakukan telaah terhadap kurikulum matematika, berbagai teori belajar yang relevan dan tantangan serta tuntutan masa depan, sehingga diperoleh deskripsi pola pembelajaran yang dianggap sesuai.

\section{b. Analisis mahasiswa (learner analysis)}

Pada langkah ini dilakukan telaah tentang karakteristik mahasiswa yang sesuai dengan rancangan dan pengembangan perangkat bahan ajar. Karakteristik tersebut meliputi kompetensi, pengalaman yang telah dimiliki, dan sikap mahasiswa terhadap pembelajaran matematika. Temuan pada bagian ini adalah mahasiswa prodi PGSD mempunyai kemampuan yang cukup untuk menyelesaikan soal problem solving. Hanya saja mereka tidak banyak diberikan kesempatan selama ini.

\section{c. Analisis konsep (concept analysis)}

Kegiatan analisis konsep ini bertujuan untuk mengidentifikasi, merinci dan menyusun secara sistematis konsep-konsep relevan yang akan diajarkan berdasarkan analisis awal-akhir. Analisis ini membantu mahasiswa dalam mengidentifikasi pertanyaan-pertanyaan yang merupakan contoh konsep yang digunakan sebagai rambu-rambu pengembangan berkaitan dengan materi pembelajaran.

\section{d. Analisis tugas (task analysis)}

Kegiatan ini merupakan pengidentifikasian keterampilan-keterampilan utama yang diperlukan dalam pembelajaran dan menganalisis kegiatan-kegiatan belajar yang diperlukan untuk menguasai keterampilan tersebut. Analisis tugas membahas secara mendalam kegiatan belajar agar kegiatan-kegiatan belajar yang dimunculkan dalam pembelajaran dapat menunjang keberhasilan proses pembelajaran yang baik. Adapun temuan yang diperoleh dalam hal ini adalah bahwa mahasiswa senang belajar secara berkelompok. Kemudian ketika mereka akan mengerjakan tugas yang diberikan semacam lembar kerja mahasiswa, mereka menginginkan adanya bantuan media/alat peraga. Lebih lanjut ketika mereka bekerja dalam kelompok adanya bantuan dari pembimbing, baik itu dari dosen ataupun dari teman sebaya.

e. Spesifikasi tujuan pembelajaran (specifying instructional objectives)

Spesifikasi tujuan pembelajaran ini bertujuan untuk mengkorvensi tujuan dari analisis tugas dan analisis konsep menjadi tujuan pembelajaran khusus, yang dinyatakan dengan tingkah laku. Perincian tujuan pembelajaran tersebut merupakan dasar dalam penyusunan tes hasil belajar berupa kemampuan penalaran matematika dan rancangan bahan ajar. Kemudian semua hal yang berkaitan dengan tes dan rancangan pembelajaran tersebut diintegrasikan kedalam suatu bahan ajar.

\section{Tahap Studi Pengembangan}

Data yang didapatkan dan dikumpulkan pada tahap studi pendahuluan digunakan sebagai draft rancangan bahan ajarproblem solving 
berbasis open-ended. Dalam penyusunan bahan ajar, tim menyusun fokus materi yang akan dijadikan materi dalam bahan ajar berupa kisi-kisi rancangan bahan ajar problem solving berbasis open ended. Hal ini untuk memudahkan peneliti dalam memberikan batasan terhadap bahan ajar yang akan dihasilkan. Dalam bahan ajar ini, peneliti mengangkat empat bidang permasalahan yaitu bilangan, bangun datar, bangun ruang, dan pengukuran.

Selanjutnya draft bahan ajar yang telah dirancang diserahkan kepada tim ahli sebagai validator untuk mengecek keabsahan, kedalaman, kelayakan, dan beberapa komponen penilaian lainnya sehingga bahan ajar ini layak untuk diuji cobakan. Kemudian setelah divalidasi, bahan ajar direvisi berdasarkan saran dari validator dan dilakukan perhitungan terhadap kualitas bahan ajar berdasarkan lembar penilaian bahan ajar, baik oleh ahli materi ataupun ahli media. Dari hasil perhitungan kualitas bahan ajar problem solving berbasis open ended berdasarkan penilaian ahli materi, didapatkan rata-rata rentang skor kualitas pada kategori baik, hanya dua sub bab yang mendapatkan kategori cukup yaitu pada bab materi bangun datar dan bangun ruang. Alasannya adalah ada soal-soal yang peneliti tawarkan harus dihilangkan karena berdasarkan komponen kelayakan, soal ini kurang dari keluasan materi dan kedalaman materi, serta berdasarkan komponen akurasi materi kurang dari akurasi konsep. Alasan lainnya adalah soal yang disajikan tidak terkategori untuk masalah pemecahan masalah berbasis open ended problems, terlalu mudah. Ahli materi juga menyarankan agar tata bahasa dalam setiap permasalahan yang diajukan agar dapat direvisi, supaya pemahaman soal oleh mahasiswa tidak memberikan tafsiran ganda yang berakibat kepada keliru dalam memberikan respon. Lebih lanjut ahli materi memberikan penekanan, walaupun bahan ajar ini sudah bisa diuji coba dengan beberapa revisi, namun nanti dalam proses pembelajaran harus benar-benar diperhatikan mengenai tingkat pemahaman mahasiswa terhadap suatu masalah yang diberikan. Jika nanti masalah yang sudah dirancang terlalu tinggi, maka seyogianya nanti masalah tersebut dapat diturunkan dan disesuaikan kembali dengan kemampuan mahasiswa.

Adapun saran lainnya dari ahli media terhadap bahan ajar yang telah dihasilkan adalah menambahkan ilustrasi berupa gambar dalam soal dan memperbaiki kalimat yang kurang jelas. Dalam proses pembelajarannya juga ditekankan pada keaktifan kelompok dan penggunaan media/ alat peraga untuk memudahkan mahasiswa dalam menyelesaikan permasalahan yang diberikan.

Berdasarkan hasil penilaian dari ahli mengenai bahan ajar problem solving berbasis open ended, selanjutnya tim merivisi bahan ajar tersebut. Revisi bahan ajar difokuskan pada kaidah tata bahasa dan menambahkan ilustrasi pada masalah yang ada dalam bahan ajar. Setelah bahan ajar dan perangkat tes tervalidasi, maka bahan ajar siap untuk digunakan dalam uji coba terbatas dan uji coba yang lebih luas.

Uji coba terbatas dilaksanakan pada unit 2-A Prodi PGSD dengan jumlah mahasiswa 35 orang.Uji coba ini dilaksanakan sebanyak 3 tahap dimana tahap pertama dilaksanakan sebanyak 16 kali tatap muka sesuai dengan banyaknya bahan ajar yang telah dirancang. Kemudian tahap kedua dilaksanakan sebanyak 5 kali meninjau dari kesulitan atau kekurangan mahasiswa dalam memahami bahan ajar yang diterapkan, dan tahap ketiga dilaksanakan sebanyak 3 kali tatap muka. Setiap selesai pengujian selalu ada revisi terhadap bahan ajar yang telah dirancang. Pengujian terbatas menggunakan model eksperimen dengan disain single one shot case study, di mana adanya perlakuan pembelajaran menggunakan bahan ajar problem solving berbasis open-ended pada pembelajaran matematika untuk melihat kemampuan penalaran mahasiswa PGSD.

Uji coba lebih luas dilaksanakan pada tiga unit di Prodi PGSD, yaitu unit 2-A, 2-B, dan $2-\mathrm{C}$ dengan menggunakan model eksperimen disain one group pretest-postest. Setiap unit 
dilakukan pengujian selama tiga kali, yaitu ujicoba 4 , ujicoba 5, dan ujicoba 6 sebagai keberlanjutan dari ujicoba terbatas yang telah dilaksanakan pada unit 2-A.Sebelum dilakukannya ujicoba untuk masingmasing unit, setiap unit diberikan perlakuan pembelajaran dengan menggunakan bahan ajar problem solving berbasis open ended yang telah direvisi hasil dari pengujian pada ujicoba terbatas pada unit 2-A.

Dari keseluruhan ujicoba, baik ujicoba terbatas maupun ujicoba yang lebih luas menunjukkan hasil yang baik untuk setiap unit dari 2-A, 2-B, dan 2-C. Setiap nilai tes menunjukkan peningkatan walaupun tidak terlalu signifikan jika dibandingkan postes 1 dan pretes 1 , postes 2 dan pretes 2 , serta postes 3 dan pretes 3. Namun jika dibandingkan antara postes 3 dengan pretes 1, mahasiswa PGSD menunjukkan pengembangan yang sangat berarti dan signifikan. Sehingga hasil dari ujicoba terbatas dan ujicoba yang lebih luas menunjukkan bahwa bahan ajar problem solving berbasis open ended sudah mulai mengembangkan kemampuan penalaran mahasiswa, walaupun belum signifikan.

\section{KESIMPULAN}

Berdasarkan hasil paparan yang telah dikemukakan dapat diambil kesimpulan bahwa telah diperoleh rancangan draft bahan ajarproblem solving berbasis open ended pada pembelajaran matematika untuk mengembangkan kemampuan penalaran mahasiswa PGSD. Rancangan bahan ajar ini akan dievaluasi dan disempurnakan kembali. Adapun desain bahan ajar yang sesuai dilaksanakan oleh mahasiswa PGSD Universitas Almuslim adalah (1) merancang kisi-kisi bahan ajar yang didalamnya memuat indikator-indikator yang akan dicapai oleh mahasiswa berdasarkan studi pendahuluan; (2) menjabarkan indikator tersebut dalam bentuk soa-soal pemecahan masalah berbasis open ended dengan mempertimbangkan kemampuan mahasiswa berdasarkan studi lapangan; (3) Bahan ajar telah divalidasi oleh dua ahli, yaitu ahli materi dan ahli media; (4)
Merevisi bahan ajar sesuai dengan saran dari validator; (4) Bahan ajar telah diujicobakan secara terbatas dan lebih luas; dan (5) soalsoal tersebut pada saat uji coba dipecahkan oleh mahasiswa secara berkelompok yang berjumlah 3-4 mahasiswa.

\section{DAFTAR PUSTAKA}

Alfeld, Peter. (1996). Understanding Mathemathics. [online]. Tersedia: http://www.math. utah. edu/ pa/math/polya.html. [ 20 April 2014].

Depdiknas. (2002). Ringkasan Kegiatan Belajar Mengajar. Jakarta: Depdiknas.

Devi Emilya, Darmawijoyo, Ratu Ilma Indra Putri. (2010). Pengembangan Soal-Soal Open-Ended Materi Lingkaran Untuk Meningkatkan Penalaran Matematika Siswa Kelas VIII Sekolah Menengah Pertama Negeri 10 Palembang. JURNAL PENDIDIKAN MATEMATIKA, VOLUME 4. NO.2, DESEMBER 2010

Jasmaniah, Fachrurazi, dan Ety Mukhlesi Yeni (2012). Pengembangan Bahan Ajar Berbasis Number Sense dan RME terhadap Kemampuan Operasi Hitung Bilangan pada Siswa Kelas VSD. Jurnal Ilmiah Sains dan Tekhnologi Vol.14, No.1. Januari 2014.

Kirkley, Jamie. (2003). Principles for Teaching Problem Solving. Plato Learning, Inc

Murni, A. (2003). Peningkatan Kemampuan Pemecahan Masalah dan Representasi Matematis Siswa SMP Melalui Pembelajaran Metakognitif Berbasis Soft Skills.Tesis.Respository: Universitas Pendidikan Indonesia.

NCTM. (1989). Curriculum and Evalutioan Standards for School Mathematics. Reston, VA: NCTM.

National Council of Teachers of Mathematics.(2000). Prinsiples and Standards for School Mathematics. Reston: NCTM.

National Council of Teachers of Mathematics.(2003). NCTM Program Standards.Programs for Initial Preparation of Mathematics Teachers. Standards for Secondary Mathematics Teachers.[Online]. Tersedia: http://www.nctm.org/ uploadedFiles/ Math_Standards/ [ 20 April 2014].

Nur Anwar, Rahmah Johar, Dadang Juandi (2014). Pengembangan Perangkat Pembelajaran Berbasis Pendekatan Open-Ended untuk Meningkatkan Kemampuan Berpikir 
Kreatif Matematis Siswa SMP. Jurnal Didaktik Matematika Vol. 2, No. 1, April 2015.

Pui Yee. (2007). Teaching secondary School Mathematics. A Resourse Book second Edition. Mthematics and mathematics Education National Institute of Education Nanyang technological University Singapore.

Shadiq, Fajar. 2004. Penalaran, Pemecahan Masalah, dan Komunikasi Dalam Pembelajaran Matematika. Disajikan pada Diklat Instruktur Matematika SMP Jenjang Dasar, 10-23 Oktober 2004. Dirjen Dikdasmen PPPG Matematika Jogjakarta.

Sugiyono. (2009). Metode Penelitian Pendidikan Pendekatan Kuatitatif, Kualitatif, dan $R \& D$. Bandung: Alfabeta.

Supriadi. (2009). Analisis Proses Berpikir Matematika antara Dosen, Mahasiswa (Guru SD \& Non Guru SD) PGSD dan Siswa SD dalam Pembelajaran Matematikadi Propinsi Banten. Bandung: Prosiding Seminar Nasional Matematika dan Pendidikan Matematika, 19 Desember 2009 Jurusan Pendidikan Matematika FPMIPA UPI.

Susetyo, B. (2010). Statistika Untuk Analisis Data Penelitian, Bandung: Refika Aditama.

Turmudi. (2008). Landasan Filsafat dan Teori Pembelajaran Matematika (berparadigma Eksploratif dan Investigasi). Jakarta: Leuser Cita Pustaka.

Wahyudin. (2010). Pembelajaran Matematika dan Pemecahan Masalah. Bandung: Mandiri Bandung. 